\title{
Biological Features and Forage Performance of Black Saxaul (Haloxylon Aphyllum (Minkw) Iljin) in the Central Asian Desert
}

\author{
Elmira Shamsutdinova* and Zebri Shamsutdinov \\ Federal Williams Research Center of Forage Production \& Agroecology, 1 Nauchnyi gorodok, \\ Lobnya, Russia
}

\begin{abstract}
Haloxylon aphyllum (Minkw.) Iljin is a treelike shrub from the Chenopodiaceae family with a thick, gnarled, highly branched trunk with dark gray bark. It is propagated by seeds. The most typical conditions of natural habitat are valley-like depressions of ridges and hollows of hilly sands, valleys and channels of old rivers, often with more or less close groundwater occurrence, as well as takyrs and takyr-like serozem soils. Black saxaul has a powerfully developed, deeply penetrating root system that reaches the level of groundwater or moist soil layers. The eaten part of black saxaul in the autumn-winter period is annual shoots, last year's twigs, fruits. It contains $10-12 \%$ protein (in fruits up to $20 \%$ ), $2.2-2.7 \%$ fat, $21.2-38.6 \%$ ash substances, up to $39.3 \%$ nitrogen-free extractive substances and up to $14.9 \%$ fiber. At the age of five to six years, the plant height reaches 4-6 m, and the root system deepens by 14-16 m. Productive longevity is $35-45$ years. It begins to vegetate in late March - early April with development of generative shoots. Flowering coincides with development of generative shoots. The flowering period lasts 10-20 days. Black saxaul, depending on the growing conditions, enters the fruiting phase in the 2-4th year of life. When creating pasture shelter strips, forage productivity on adjacent natural pastures at a distance of up to $100 \mathrm{~m}$ increases by $20-30 \%$. In the strip itself, the yield of small grasses increases 2-3 times. The total forage productivity of pastures improved by crops of black saxaul considering the yield of adjacent pastures, increases 2 times.
\end{abstract}

\section{Introduction}

Black saxaul, saline or leafless ( Haloxylon aphyllum (Minkw) I1jin) is a treelike shrub from the Chenopodiaceae family that grows in the deserts of Central Asia and Kazakhstan [1]. The most typical conditions of natural habitat are valley-like depressions of ridges and

\footnotetext{
*Corresponding author’s e-mail: darplant@list.ru
} 
hollows of hilly sands, valleys and channels of old rivers, often with a relatively close occurrence of groundwater [2,3].

The range of black saxaul covers Iran, Afghanistan, Central Asia, Kazakhstan.

The eaten part is assimilative shoots and fruits, which are quite satisfactory food for sheep and camels. Saxaul feed contains $10-12 \%$ protein (in fruits up to $20 \%$ ), 2.2-2.7\% fat, 28.9-38.6 \% ash substances and up to $39.3 \%$ nitrogen-free extractive substances [4].

Black saxaul is a plant with high forage productivity. The yield of forage mass under natural growing conditions is up to $1.0 \mathrm{t} / \mathrm{ha}$, and under culture conditions - from $0.5-0.8$ to $1.6 \mathrm{t} / \mathrm{ha}$ of dry forage mass [4].

Black saxaul according to ecology is haloxerophyte $[5,6]$, according to the adaptive strategy of violent according to L.G. Ramensky [7], according to J. Grime is a competitor [8].

Black saxaul has a high environment-forming and environment-improving function [9]. High phyto-meliorative properties in combination with forage advantages make this woody shrub a promising species for creating pasture protection strips and multi-species long-term pastures in the Central Asian desert.

The purpose of this paper is to study the biological characteristics of black saxaul in culture for effective use in pasture farming in the Central Asian desert.

\section{Methods}

The studies were carried out in three ecologically different regions of the Central Asian Desert.

Foothill desert Nishan "steppe". The experimental site is located at an altitude of $354 \mathrm{~m}$ above sea level, $\mathrm{m}$. The soil cover is represented mainly by light gray soils. A characteristic feature of the soil profile is its layered structure: horizons of light, medium and heavy loams, as well as sandy loam, alternate. The soils are largely saline and can be classified as saline. Groundwater occurs at the depth of 12-14-20 m. Average annual air temperature is $+14.8^{\circ} \mathrm{C}$, maximum one is $+47^{\circ} \mathrm{C}$, minimum one is $-27^{\circ} \mathrm{C}$. The coldest month is January, the temperature sometimes drops to $-30^{\circ} \mathrm{C}$. Average annual precipitation is $222 \mathrm{~mm}$.

Wormwood-ephemeral Karnabchul desert. The experimental site is located at an altitude of $310 \mathrm{~m}$ above sea level, $\mathrm{m}$. The dominant type of soils is light gray soils and transitional from light gray soils to gray-brown. Groundwater occurs at a depth of $14-20 \mathrm{~m}$. The average annual air temperature is $+16^{\circ} \mathrm{C}$, in June - July in the shade it reaches 40 $45^{\circ} \mathrm{C}$, and in January it sometimes drops to minus $20-30{ }^{\circ} \mathrm{C}$. The relative air humidity for the year is on average $30 \%$, in spring, and especially in summer, it drops to $10-20 \%$. The average annual amount of precipitation is $167 \mathrm{~mm}$.

Desert Southwest Kyzyl Kum. The experimental site is located at an altitude of $184 \mathrm{~m}$ above sea level, $\mathrm{m}$. The soils are desert-sandy. The soil profile is quite clearly differentiated into genetic horizons. Soils from the surface to a depth of $90 \mathrm{~cm}$ are represented by light sandy loams, below (from 90 to $225 \mathrm{~cm}$ ) - by sands. The upper and lower layers of the soil are not saline. The groundwater level is deeper than $100 \mathrm{~m}$. The average annual air temperature is $+14.6^{\circ} \mathrm{C}$. The hottest month is July, average monthly temperature is + 20.0-33. $2^{\circ} \mathrm{C}$, maximum one is $+46.6{ }^{\circ} \mathrm{C}$. The average annual relative air humidity is $47 \%$, in summer (July) - 16-30\%. Average long-term precipitation is $110 \mathrm{~mm}$.

Features of seed germination of black saxaul, growth and development of plants, ecology of flowering and pollination, fruiting, the method of accounting for forage and seed productivity were carried out in accordance with the "Methodological instructions ..." [10]. 


\section{Results}

Phenology. Vegetation of black saxaul growing in culture begins in late February - early March. Budding was noted in March - April. It blooms in April for one to two weeks. During the period of mass flowering, the trees acquire a yellowish tint from the abundance of pollen. After the end of flowering, intensive growth of vegetative branches begins and during the whole summer no morphological changes are observed on the generative shoots. Only at the end of September - October, the growth of the pericarp, consisting of five transparent membranous lionfish, begins. This is the beginning of formation of fruits, which ripen in the second half of October - early November.

Laboratory and field germination of seeds. Laboratory germination of seeds, depending on their quality, ranges from 18.0 to $92.5 \%$. Field germination rate ranges from $0.5-1.0$ to $28.8 \%$. Seeding the seeds to the optimum depth $(1.0 \mathrm{~cm})$ and post-sowing rolling improve the water supply conditions, which makes it possible to increase the field germination capacity of seeds by 2-5 times.

Dynamics of standing density and survival of black saxaul specimens. In the foothill desert of the Nishan "steppe" in the first year of life, the survival rate of plants was $73.7 \%$, in the second year $-59.0 \%$, in the wormwood-ephemeral desert at the end of the second year of vegetation $-67.3 \%$. In subsequent years, both in the foothill desert and in the wormwood-ephemeral desert, the stand density stabilizes, and practically no plant loss is observed.

Table 1 shows the data characterizing the growth of the aerial part of black saxaul in the first year of life in different soil and climatic conditions of the Central Asian desert.

65-80 days after sprouting, black saxaul plants reach $15.8-20.8 \mathrm{~cm}$ in height with an average crown diameter of $14.3-20.6 \mathrm{~cm}$. The diameter of the trunk is $0.33-0.46 \mathrm{~cm}$. A noticeable difference is observed in the accumulation of organic matter by plants growing in different soil and climatic conditions. The dry weight of one plant in the wormwoodephemeral desert is 45.4-58.5 g, and in the foothill desert is much lower $-38.3 \mathrm{~g}$, in the Southwestern Kyzyl Kum desert is even less - $28.4 \mathrm{~g}$.

The growth of black saxaul and the accumulation of plant mass continues in the second half of the growing season. At the end of September, the height of plants doubles compared to June. The best growth rates and the largest dry weight of one bush is characteristic of the population in the wormwood-ephemeral desert, and in the foothill desert and South-West Kyzyl Kum, it is characterized by low growth and less dry weight of one bush. Despite significant differences in growth rates, in general, this shrub forms well-developed plants in the first year of life.

Table 1. Features of growth and development of the aerial part of black saxaul in the first year of life in different soil and climatic conditions of the Central Asian desert.

\begin{tabular}{|c|c|c|c|c|c|c|}
\hline \multirow[b]{2}{*}{$\begin{array}{c}\text { Characteristics of } \\
\text { natural areas }\end{array}$} & \multirow[b]{2}{*}{ Farm } & \multicolumn{5}{|c|}{ First year, September } \\
\hline & & $\begin{array}{c}\text { Number } \\
\text { of plants } \\
\text { per } 1 \\
\text { hectare, } \\
\text { pcs. }\end{array}$ & $\begin{array}{c}\text { Plant } \\
\text { height, } \mathrm{cm}\end{array}$ & $\begin{array}{l}\text { Crown } \\
\text { diameter } \\
, \mathrm{cm}\end{array}$ & $\begin{array}{c}\text { Stem } \\
\text { diameter, } \\
\mathrm{cm}\end{array}$ & $\begin{array}{c}\text { Dry } \\
\text { forage } \\
\text { weight } \\
\text { from } 1 \\
\text { bush, g }\end{array}$ \\
\hline $\begin{array}{l}\text { Wormwood- } \\
\text { ephemeral desert. } \\
\text { Light, sandy loam } \\
\text { gray soils, annual } \\
\text { precipitation - } \\
160 \mathrm{~mm} \text {. } \\
\text { Groundwater level is } \\
16-25 \mathrm{~m}\end{array}$ & Karnab & 723 & 47.2 & 46.8 & 0.95 & 75.5 \\
\hline
\end{tabular}




\begin{tabular}{|l|l|l|l|l|l|l|}
\hline $\begin{array}{l}\text { Wormwood- } \\
\text { ephemeral desert. } \\
\text { Light sandy loam } \\
\text { gray soils, annual } \\
\text { precipitation - } \\
160 \mathrm{~mm} .\end{array}$ & Mubarek & 814 & 37.6 & 38.4 & 0.83 & 60.0 \\
$\begin{array}{l}\text { Groundwater level of } \\
20-40 \mathrm{~m}\end{array}$ & & 1,023 & 30.7 & 26.8 & 0.62 & 52.9 \\
\hline $\begin{array}{l}\text { Foothill desert. Light } \\
\text { loamy gray soils, } \\
\text { annual precipitation - } \\
224 \text { mm. }\end{array}$ & Nishan \\
$\begin{array}{l}\text { Groundwater level of } \\
15-45 \mathrm{~m}\end{array}$ & & & & & & \\
\hline $\begin{array}{l}\text { Southwest Kyzyl } \\
\text { Kum. Desert-sandy } \\
\text { soils, annual } \\
\text { precipitation of }\end{array}$ & Kokcha & 1,245 & 35.1 & 39.0 & 0.86 & 50.0 \\
$\begin{array}{l}\text { Groundwater level of } \\
\text { below } 100 \mathrm{~m}\end{array}$ & & & & & & \\
\hline
\end{tabular}

In the desert zone of the Nishan "steppe", experiments were made to study the seeding rates of black saxaul seeds. Full-fledged seedlings appeared in the spring. Data given in Table 2 shows that the average plant height in mid-May is only $5.2-6.0 \mathrm{~cm}$, by the end of June - 22.1-26.4, in early August 48.4-51.6, by the end of the growing season - 66.9$72.5 \mathrm{~cm}$.

Plants of black saxaul were relatively tall with a well-developed stem. Each bush had 610 well-lignified branches of the first order.

Table 2. Growth dynamics of black saxaul plants depending on the seeding rate in the foothill desert of the Nishan "steppe".

\begin{tabular}{|c|c|c|c|c|c|}
\hline \multirow{3}{*}{$\begin{array}{l}\text { Seeding rate, } \\
\mathrm{kg} / \mathrm{ha}\end{array}$} & \multirow{3}{*}{$\begin{array}{l}\text { Standing } \\
\text { density, } \\
\text { pcs./ha }\end{array}$} & \multicolumn{4}{|c|}{ Plant height, $\mathrm{cm}$} \\
\hline & & \multicolumn{4}{|c|}{ 1st year } \\
\hline & & $15 . \mathrm{V}$. & 27.VI. & 3.VIII. & 27. VIII. \\
\hline 3 & 9,650 & $5.27 \pm 0.42$ & $22.15 \pm 1.4$ & $50.34 \pm 5.32$ & $67.2 \pm 3.9$ \\
\hline 6 & 13,800 & $5.3 \pm 0.2$ & $25.4 \pm 1.2$ & $50.6 \pm 2.9$ & $70.4 \times 2.7$ \\
\hline 9 & 13,400 & $5.5 \pm 0.2$ & $25.2 \pm 0.7$ & $48.4 \pm 3.9$ & $72.5+1.9$ \\
\hline 12 & 14,300 & $6.0 \times 0.12$ & $26.4 \pm 1.4$ & $51.6 \pm 1.7$ & $71.9 \pm 3.0$ \\
\hline 18 & 16,200 & $5.4 \pm .14$ & $23.7 \pm 1.6$ & $47.8 \pm 1.1$ & $66.9 \pm 1.8$ \\
\hline \multirow{2}{*}{$\begin{array}{ll}\text { Seeding } & \text { rate } \\
\mathrm{kg} / \mathrm{ha} & \end{array}$} & \multicolumn{5}{|c|}{ Plant height, $\mathrm{cm}$} \\
\hline & 2nd year & & 3rd year & year & 5 th year \\
\hline 3 & $121.6 \pm 7.8$ & \multicolumn{2}{|c|}{$129.6 \pm 8.1$} & $7 \pm 10.2$ & $198.9 \pm 12.4$ \\
\hline 6 & $106.5 \pm 6.2$ & \multicolumn{2}{|c|}{$126.8 \pm 15.2$} & $9+19.4$ & $181.2 \pm 27.5$ \\
\hline 9 & $109.3 \pm 5.2$ & \multicolumn{2}{|c|}{$127.1 \pm 8.6$} & $.0 \pm 2.5$ & $168.2 \pm 10.0$ \\
\hline 12 & $113.9+7.0$ & \multicolumn{2}{|c|}{$123.5 \pm 8.7$} & $2 \pm 7.2$ & $180.8 \pm 12.7$ \\
\hline 18 & $112.6 \pm 8.7$ & \multicolumn{2}{|c|}{$126.2+96$} & $.7 \pm 6.3$ & $195.8 \pm 8.5$ \\
\hline
\end{tabular}

In subsequent years, linear growth continued. In the second year of life, the average plant height reached $106-121 \mathrm{~cm}$, in the third $-123-129 \mathrm{~cm}$, in the fourth $-152-179 \mathrm{~cm}$, in the fifth $-168-198 \mathrm{~cm}$.

Observations have shown that at the age of 3-4 years, skeletal axes are mainly formed, some bushes bear fruit for 3-4 years, but as a rule, from 5 years.

We have determined different growth parameters of black saxaul in different environmental conditions. Data from Table 3 show that in the foothill desert at the age of 4- 
5 years, the bushes grow up to $145-173 \mathrm{~cm}$. In this case, the crown diameter is $82-160 \mathrm{~cm}$, and the trunk thickness is $2.6-4.9 \mathrm{~cm}$.

Table 3. Growth and development indicators of black saxaul in various ecological conditions of the Central Asian desert.

\begin{tabular}{|c|c|c|c|c|c|c|c|}
\hline Zone & $\begin{array}{l}\text { Tract, plant } \\
\text { age }\end{array}$ & $\begin{array}{l}\text { Sow } \\
\text { ing } \\
\text { area } \\
\text {, ha }\end{array}$ & $\begin{array}{c}\text { Numb } \\
\text { er of } \\
\text { bushe } \\
\text { s per } \\
1 \text { ha, } \\
\text { pcs. }\end{array}$ & $\begin{array}{l}\text { Plant } \\
\text { height, } \\
\mathrm{cm}\end{array}$ & $\begin{array}{c}\text { Crown } \\
\text { diameter, } \\
\mathrm{cm}\end{array}$ & $\begin{array}{c}\text { Stem } \\
\text { diameter, } \\
\mathrm{cm}\end{array}$ & $\begin{array}{c}\text { The } \\
\text { number of } \\
\text { fruiting } \\
\text { bushes, } \%\end{array}$ \\
\hline \multirow{2}{*}{$\begin{array}{l}\text { Foothill } \\
\text { desert }\end{array}$} & Kzylcha, (4) & 500 & 4,582 & $145 \pm 8.3$ & $82 \pm 4.3$ & $2.6 \pm 0.1$ & 36.5 \\
\hline & Kaftarli, (5) & 500 & 1,687 & $173 \pm 11.3$ & $160 \pm 9.5$ & $4.9 \pm 0.4$ & 77.3 \\
\hline \multirow{3}{*}{$\begin{array}{l}\text { Piedmont } \\
\text { wormwood- } \\
\text { ephemeral } \\
\text { desert }\end{array}$} & $\begin{array}{l}\text { Yarmachi, } \\
(10)\end{array}$ & 400 & 905.6 & $459 \pm 19.4$ & $323 \pm 21.0$ & $13.5 \pm 1.0$ & 71.2 \\
\hline & Planchop, (5) & 500 & 1,545 & $205 \pm 6.5$ & $178 \pm 6.7$ & $5.3 \pm 0.3$ & 54.3 \\
\hline & Gumbasa, (4) & $\begin{array}{c}2,00 \\
0\end{array}$ & 1,039 & $137 \pm 17.0$ & $125 \pm 12.3$ & $3.8 \pm 0.4$ & 59.7 \\
\hline \multirow{2}{*}{$\begin{array}{l}\text { Piedmont } \\
\text { wormwood- } \\
\text { ephemeral } \\
\text { desert }\end{array}$} & $\begin{array}{l}\text { Tanikuduk, } \\
\text { (5) }\end{array}$ & 200 & 1,819 & $282 \pm 17.1$ & $199 \pm 18.7$ & $6.9 \pm 0.6$ & 57.4 \\
\hline & Sahaba, (7) & 200 & 2,857 & $274 \pm 18.2$ & $201 \pm 17.0$ & $6.9 \pm 0.6$ & 61.5 \\
\hline \multirow{2}{*}{$\begin{array}{l}\text { Piedmont } \\
\text { wormwood- } \\
\text { ephemeral } \\
\text { desert } \\
\end{array}$} & Aytuvdy, (5) & 500 & 939 & $217 \pm 11.7$ & $191 \pm 3.9$ & $5.9 \pm 0.3$ & 85.8 \\
\hline & Aytuvdy, (4) & 500 & 1,393 & $195 \pm 8.5$ & $163 \pm 12.5$ & $4.7 \pm 0.5$ & 75.1 \\
\hline \multirow[t]{2}{*}{$\begin{array}{l}\text { Southwest } \\
\text { Kyzyl Kum }\end{array}$} & $\begin{array}{l}\text { Maya-Tyube, } \\
\text { (5) }\end{array}$ & 200 & 2,574 & $100 \pm 17.5$ & $107 \pm 23.0$ & $3.0 \pm 0.6$ & 13.2 \\
\hline & Aksai, (4) & 500 & 4,450 & $80 \pm 10.0$ & $72 \pm 10.5$ & $2.0 \pm 0.3$ & 32.9 \\
\hline
\end{tabular}

Black saxaul growing in the Southwestern Kyzylkum mountains noticeably lagged behind in growth: the height of five-year-old bushes did not exceed 80-107 cm.

At the age of 4-5 years, black saxaul, growing in artificial pasture shelter plantations, bore fruit. However, the number of fruiting plants was not the same in all natural zones. In the foothill desert it was 36.5-77.3\%, in the wormwood-ephemeral desert - 54.3-85.8, in the South-Western Kyzyl Kum desert it did not exceed 13.2-32.9\%.

In general, black saxaul is a fast-growing shrub, reaching a height of half a meter in the first year of life, at the age of 4-5 years - 2-3 meters, at the age of 10 years - 4-5 meters.

From the point of view of forage value, it is most advisable to have young and midseason stands of black saxaul in sheep-breeding farms. Sheep eat well the bushes that are abundantly overgrown with annual shoots. One of the shortest ways to get young growth is to rejuvenate the bushes. So, in the Karnab farm, the above-ground part of the black saxaul at the age of 8-11-12 years old was alienated at a height of $50 \mathrm{~cm}$. The next year, we received shoots of numerous shoots with a length of 40-60 to $120-150 \mathrm{~cm}$ with a bush diameter of $80-150 \mathrm{~cm}$. In the third or fourth year, the height of the undergrowth bushes reached $150-250 \mathrm{~cm}$ with a crown width of $170-200 \mathrm{~cm}$.

Rejuvenation of black saxaul lengthens their life as a pasture plant. The growing shoots of rejuvenated bushes are more nutritious and juicier than those of adults and middle-aged individuals. The alienated wood is used in sheep-breeding farms for fuel, which eliminates the need to cut down shrubs, namely, wormwood.

Forage productivity of black saxaul. Black saxaul growing in culture is characterized as a highly productive fodder plant.

Pastures improved by creating black saxaul pasture shelter strips, in terms of yield, were 4 times higher than natural forage lands. On average, over 4 years, the total yield of saxaul 
plantations with wormwood and ephemerals in the Karnab farm was $2.2 \mathrm{t} / \mathrm{ha}$, on a natural wormwood-ephemeral pasture $-0.5 \mathrm{t} / \mathrm{ha}$ of dry weight.

Table 4. Forage productivity of black saxaul in various ecological conditions of the Central Asian desert.

\begin{tabular}{|l|c|c|c|c|}
\hline \multicolumn{1}{|c|}{ Farm } & Tract & $\begin{array}{c}\text { Age, } \\
\text { years }\end{array}$ & $\begin{array}{c}\text { Number of } \\
\text { bushes per 1 ha, } \\
\text { pes. }\end{array}$ & $\begin{array}{c}\text { Dry forage mass, } \\
\text { t/ha }\end{array}$ \\
\hline \multicolumn{5}{|c|}{ Foothill desert } \\
\hline \multirow{2}{*}{ Nishan } & Kyzylcha & 4 & 4,582 & $1.4 \pm 1.7$ \\
\cline { 2 - 5 } & Kaftarli & 5 & 1,687 & $1.6 \pm 2.7$ \\
\hline Wormwood-ephemeral desert & Yarmachi & 10 & 905.6 & $6.1 \pm 7.0$ \\
\hline \multirow{2}{*}{ Karnab } & Planchop & 5 & 1,545 & $3.0 \pm 5.0$ \\
\hline $\begin{array}{l}\text { Leninichi } \\
\text { Chorvador }\end{array}$ & Sahaba & 7 & 2,857 & $4.4 \pm 9.0$ \\
\hline Karakum & Tanykuduk & 5 & 1,819 & $3.1 \pm 3.1$ \\
\hline Southwest Kyzyl Kum & Aytuvdy & 5 & 939 & $2.5 \pm 5.8$ \\
\hline Kanimeh & Aksai & 4 & 3,633 & $0.6 \pm 1.9$ \\
\hline Kokcha & Maya-Tyube & 5 & 2,574 & $0.6 \pm 1.3$ \\
\hline
\end{tabular}

From Table 4 it follows that in the farm Nishan located in the lower strip of the foothill desert, the yield of black saxaul strips was 1.4-1.6 t/ha of dry weight. The productivity of black saxaul in the zone of the wormwood-ephemeral desert was much higher: in the Karnab farm, the yield of fodder mass was 3.0-6.1 t/ha, in Leninchi Chorvador - 3.1-4.4 and in the Karakum $-2.5 \mathrm{t} / \mathrm{ha}$ of dry fodder mass. The black saxaul fodder lands created on the farms of the South-West Kyzyl Kum were characterized by the lowest productivity (0.6 t/ha).

\section{Discussion}

Ecologically black saxaul is xerohalophyte combining features of euxerophyte and hyperhalophyte. These ecological features of black saxaul determine its ability to economically use soil moisture for transpiration. In April, when the hydrothermal conditions are favorable, the transpiration rate of black saxaul is $301.6 \pm 20.9 \mathrm{mg} / \mathrm{h}$ per 1 of wet weight, for salt-loving wormwood of $698.5 \pm 75.1$ it is 2 times higher, for gray teresken of $1,105.8 \pm 123.1 \mathrm{mg} / \mathrm{h}$ per 1 wet weight, 3 times more than that of black saxaul. This indicates a high drought tolerance and the ability of black saxaul to consume moisture for transpiration economically.

In the middle of summer, under conditions of increased stress of meteorological factors, the transpiration rate in saxaul was at the level of $312.9 \mathrm{mg} / \mathrm{h}$ per $1 \mathrm{~g}$ of fresh weight. In mid-August, the intensity of transpiration in plants remained at the July level $-327.7 \mathrm{mg} / \mathrm{h}$ per $1 \mathrm{~g}$ of wet weight. With the onset of the xerothermal season at the height of summer (July-August), the intensity of transpiration, following the increase in the tension of meteorological factors, shall have increased. However, this does not happen. During this period, the plant's ability to retain water in its cells and tissues and maintain the required level of water content is provided by accumulation of osmotically active substances in its cells (sugar, betaine, proline) $[6,11]$. Accumulation of compatible osmolytes is vital for osmoregulation of cells, the protection of cellular structures [12], and the maintenance of protein formations [13]. Osmotic regulation plays an important role in ensuring the resistance of black saxaul to water deficit. 
Within evolution and natural selection of plants from mesophytes to haloxerophytes, the structural organization of the plant organism was rearranged. This primarily affected the photosynthetic and transpiring organs of plants - leaves [14]. In the haloxerophytic shrub black saxaul, the lamellar forms of leaves have turned into cylindrical succulent formations, many times reducing the surface of the leaves [15].

Black saxaul has developed other special mechanisms of resistance not only to water deficiency, but also to salt stress in the process of phylogenetic development - the ability to maintain low concentrations of salts in the cytoplasm by accumulating them in vacuoles. This ensures exclusion of the osmotic and toxic effects of salts with the simultaneous synthesis and accumulation of non-toxic (compatible) osmolytes in cytolysis [16].

The high degree of xerophilization in combination with increased salt tolerance allows the plant organism of black saxaul to function for a long time and successfully in the harsh xerothermal arid conditions of the Central Asian desert, as well as to survive a long dry summer period.

In the careful and efficient use of scarce soil moisture reserves in the Central Asian Desert, an important role is played by the fact that black saxaul is a plant by the type of photosynthesis $\mathrm{C}_{4}$. As is known, a plant using this type of photosynthesis uses much less water to fix carbon and create organic matter $[17,18]$.

\section{Conclusion}

Black saxaul is a tree-like shrub, reaching 3-4 $\mathrm{m}$ in height in the Central Asian desert. The root system of black saxaul is characterized by rapid growth, penetrates into the soil up to 12-16 m, often reaching the groundwater level.

The eaten part of black saxaul in the autumn-winter period is annual shoots, last year's twigs, fruits. It contains $10-12 \%$ of protein (in fruits up to $20 \%$ ), 2.2-2.7 \% of fat, $21.2-$ $38.6 \%$ of ash substances, up to $39.3 \%$ of nitrogen-free extractive substances and up to $14.9 \%$ of fiber.

An important ecological and biological feature of black saxaul is the economical use of soil moisture for transpiration. This feature is associated with its belonging to the $\mathrm{C}_{4}$-type of photosynthesis, which ensures not only the thrifty consumption of moisture for evaporation, but also the efficient use of water in the process of photosynthesis. In the first year of life, black saxaul reaches half a meter in height, at the age of 4-5 years - 2-3 meters, at the age of 10 years $-4-5$ meters in height.

Black saxaul has a high environment-forming and environment-improving function. High phytomeliorative properties in combination with feeding characteristics make this tree shrub a promising species for creating pasture protection strips and multi-species long-term pastures in sheep-breeding farms of the Central Asian Desert.

The study was supported by a grant from the Russian Science Foundation (project No. 19-16-00114).

\section{References}

1. Botanicheskaya geografiya Kazahstana i Srednej Azii (v predelah pustynnoj oblasti) (2003)

2. N. Akzhigitova, Galofil'naya rastitel'nost' Srednej Azii i ee indikacionnye svojstva (1982)

3. E. Korovin, Rastitel'nost' Srednej Azii i Kazahstana, 1 (1961) 
4. Z. SHamsutdinov, I. Savchenko, N. SHamsutdinov, Galofity Rossii, ih ekologicheskaya ocenka i ispol'zovanie (2001)

5. R. Munns, Plant Cell Environ, 25 (2002)

6. I. Jang, S. Oh, J. Seo, W. Choi, S. Song, C. Kim, Y. Kim, H. Seo, Y. Choi D, B. Nahm, J. Kim, Plant Phys. 131 (2003)

7. L. Ramenskij, Problemy i metody izucheniya rastitel'nogo pokrova (1971)

8. J. Grime, Plant strategies and vegetation processes (1979)

9. N. Shamsutdinov, I. Savchenko, E. Shamsutdinova, N. Orlovsky, Z. Shamsutdinov and Yu. Kaminov, Russian Journal of Ecology 49, 6 (2018)

10. Metodicheskie ukazaniya po mobilizacii rastitel'nyh resursov i introdukcii aridnyh kormovyh rastenij (2000)

11. J. Matysik, A. Alia, B. Bhalu and P. Mohanty, Current Science, 82, 5 (2002)

12. R. Munns, M. Tester, Annual Review of Plant Biology, 59 (2008)

13. H. Askari, J. Edqvist, M. Hajheidari, M. Kafi and G. Salekdeh, Proteomics, 6 (2006)

14. N. Nechaeva, V. Vasilevskaya i K. Antonova, ZHiznennye formy rastenij pustyni Karakum (1973)

15. R. Ogburn and E. Edwards, Advances in Botanical Research, 55 (2010)

16. Z. Dajic, Physiology and Molecular Biology of Salt Tolerance in Plant (2006)

17. V. P'yankov i A. Mokronosov, Problemy osvoeniya pustyn', 3 (1991)

18. V. P'yankov, Rol' fotosinteticheskoj funkcii $\mathrm{v}$ adaptacii rastenij $\mathrm{k}$ usloviyam sredy (Avtoref. dis...dokt. biol. nauk., 1993) 